Яким’як С. В., канд. військ. наук, доцент

Кафедра Військово-Морських Сил командно-штабного інституту застосування військ (сил) Національного університету оборони України імені Івана Черняховського, Київ

\title{
Аналіз чинників, які впливають на виконання завдань Військово-Морськими Силами під час захисту економічної діяльності держави на морі в умовах гібридних дій противника
}

Резюме. У статті проведено аналіз зовнішніх і внутрішніх чинників, які впливають на ефективність застосування Військово-Морських Сил Збройних Сил України під час виконання завдань захисту економічної діяльності держави на морі в умовах гібридних дій Російської Федерації.

Ключові слова: військово-морські сили; захист економічної діяльності на морі; зовнішні та внутрішні чинники; гібридні дії.

Постановка проблеми. Унаслідок захоплення Криму та встановлення контролю Російською Федерацією (далі - РФ) над значною частиною територіального моря, виключної (морської) економічної зони (далі В(М)ЕЗ) України, об'єктів виробничої діяльності на морі, морської інфраструктури та інших складових морського потенціалу України, наша держава понесла величезні економічні збитки.

Так, агресором (РФ) захоплено та контролюється понад $50 \%$ територіального моря та внутрішніх вод України у межах Чорного й Азовського морів; порушуються суверенні права України на економічну діяльність у межах В(M)ЕЗ України, понад $90 \%$ якої захоплено та контролюється підрозділами військових формувань РФ; здійснюється незаконне управління судноплавством в акваторії захопленої ним Керченської протоки та отримується відповідна економічна вигода; захоплені та експлуатуються морські нафтогазодобувні платформи на українській частині шельфу; РФ захоплено та незаконно експлуатуються морські порти, промисловий флот, судноремонтні та суднобудівні заводи України, які були розміщені у Криму, зокрема значні збитки економіці України наносяться через захоплення причального фронту портів, які забезпечували експортно-імпортні операції України $[1,2]$.

Ці втрати Україна несе і дотепер, тому керівництвом держави вживаються відповідні заходи із забезпечення захисту національних інтересів на морі.

Зокрема, у вересні 2020 року Президентом України було затверджено Стратегію національної безпеки України, згідно 3 якою реалізація потенціалу України як морської держави $є$ одним 3 основних напрямів зовнішньополітичної та внутрішньополітичної діяльності держави для забезпечення іiі національних інтересів i безпеки [3].

До цього, постановою Кабінету Міністрів України від 18.12.2018 № 1108 була оновлена та видана в новій редакції Морська доктрина України на період до 2035 року, яка визначає стратегію та основні напрями подальшого розвитку України як морської держави, зокрема і іiі економічної складової [2].

Проте реалізації стратегії, що визначена Морською доктриною, щодо ведення Україною економічної діяльності на морі, перешкоджають гібридні дії РФ. Це обумовлює необхідність залучення до іï захисту сил (військ) Військово-Морських Сил Збройних Сил України (далі - ВMC ЗС України), на ефективність застосування яких впливає низка чинників, недостатньо вивчених на сьогодні.

Аналіз останніх досліджень i публікацій. у наукових дослідженнях останніх років питання ведення гібридних дій РФ у Чорному та Азовському морях, їх вплив на ведення економічної діяльності нашою державою та застосування ВМС 3С України для виконання завдань щодо протидії противнику вивчали I. Веремій, М. Паламарчук, А. Тарасов, I. Кабаненко,
А. Риженко,
Б. Бабін,
С. Соколюк,

А. Клименко [4-11], а також розглядались в $[12,13]$, проте аналіз впливу чинників на ефективність застосування сил (військ) не проводився.

Окремі питання аналізу чинників, які впливають на ефективність застосування ВМС під час виконання завдань захисту 
економічної діяльності держави на морі досліджували С. Г. Санніков, Й.К. Раджапакса в [14], однак у зазначеній праці розглядались умови регіону, відмінного від Чорноморського, без урахування гібридних дій противника.

Отже, аналіз праць зазначених науковців та інших наукових джерел свідчить, що питання впливу чинників на ефективність застосування ВМС під час виконання завдань захисту економічної діяльності держави на морі в умовах гібридних дій противника комплексно не розглядались i не були предметом окремого дослідження.

Метою статті $\epsilon$ визначення чинників та аналіз характеру їх впливу на застосування ВMC під час виконання завдань захисту економічної діяльності держави на морі, зокрема в умовах гібридних дій противника.

Виклад основного матеріалу. В умовах зростання негативного впливу РФ на економічну діяльність України на морі постає необхідність проведення дослідження щодо розвитку способів застосування сил (військ) ВMC під час виконання завдань захисту економічної діяльності держави на морі в умовах гібридних дій противника.

Аналіз досвіду дій флотів та поглядів іноземних $\mathrm{i}$ вітчизняних фахівців на застосування сил (військ) ВМС щодо захисту економічної діяльності на морі дав змогу визначити такі основні чинники, які впливають на виконання силами (військами) завдань:

зовнішні - вимоги міжнародних i національних нормативно-правових актів, які регламентують питання захисту економічної діяльності на морі; види та характер економічної діяльності держави на морі, яка потребує захисту; існуючий і прогнозований характер дій РФ, що негативно впливає на економічну діяльність на морі; умови району застосування сил (військ) ВМС;

внутрішні - наявний склад, стан, оперативні (бойові) спроможності сил (військ) $\mathrm{BMC}$, які можуть залучатися до виконання завдань захисту економічної діяльності на морі; рівень підготовки особового складу органів військового управління, військових частин до виконання завдань захисту економічної діяльності на морі, а також існуючі способи виконання зазначених завдань.

Розглянемо вплив зазначених чинників на ефективність застосування ВМС під час виконання вказаних завдань.

Відповідно до Конвенції ООН 3 морського права 1982 року, прибережні держави мають суверенні права у виключній економічній зоні щодо розвідування, розроблення і збереження природних ресурсів як живих, так i неживих, у водах, що покривають морське дно, на морському дні та в його надрах, а також для управління цими ресурсами, та щодо інших видів діяльності 3 економічної розвідки та розроблення зазначеної зони [15].

Правовий режим такої економічної зони України в Чорному морі визначається Законом України "Про виключну (морську) економічну зону”. До того ж, в Азовському морі подібна зона юрисдикції України обмежена, а економічна діяльність держави регламентується Договором між Україною i РФ про співробітництво у використанні Азовського моря і Керченської протоки від 24.12.2003 (далі - Договір про співробітництво) [16].

Анексія Кримського півострова призвела до подвійного тлумачення статусу внутрішніх морських вод, територіального моря та частини В(M)Е3 України навколо півострова, оскільки РФ, у порушення міжнародного законодавства, заявила права на них.

Прикриваючись законодавством, суб'єкти економічної діяльності РФ під захистом сил Чорноморського флоту Південного військового округу РФ (далі - ЧФ ПдВО РФ) 3 2014 року ведуть активну діяльність у В(М)Е3 України та на іiі шельфі, а сили ЧФ ПдВО РФ - гібридні дії щодо перешкоджання веденню такої діяльності Україною.

У порушення норм міжнародного права та національного законодавства, 25 листопада 2018 року відбулося захоплення військових кораблів ВMC 3С України поблизу Керченської протоки спеціально створеним міжвидовим угрупованням РФ під прикриттям кораблів Берегової охорони Прикордонної служби Федеральної служби безпеки РФ. Указані дії противник обгрунтовував "неправомірним заходом у територіальні води РФ”, хоча встановлення РФ в односторонньому порядку суверенітету над зазначеною акваторією прямо суперечить положенню Договору про співробітництво, відповідно до якого врегулювання питань, які стосуються акваторії Керченської протоки, здійснюється за угодою між сторонами [16]. До того ж, відповідно до резолюції 3314 (XXIX) Генеральної Асамблеї ООН від 14 грудня 1974 року, напад збройними силами однієї держави на сухопутні, морські чи 
повітряні сили, або морські та повітряні флоти іншої держави кваліфікується як акт агресії.

Водночас, від керівництва РФ лунають заяви щодо неприпустимості перегляду існуючої нормативно-правової бази щодо статусу Азовського моря i Керченської протоки, яка зокрема, забороняє захід військових кораблів або інших державних суден, які експлуатуються в некомерційних цілях, в Азовське море і прохід Керченською протокою без надання дозволу обох держав [16]. Зазначене дає підставу РФ для блокування заходу в цій акваторії військових кораблів третіх держав без їі дозволу та не дає змоги залучати сили ВМС країн - партненів до спільного виконання завдань 3 ВМС ЗС України.

Українська економіка значно залежить від морської діяльності. Як відомо, існують такі іiі види: торговельне мореплавство, морський транспорт, суднобудування, військово-морська діяльність, використання водних біоресурсів та інших ресурсів моря, туристична та рекреаційна діяльність, а також діяльність у сферах науки, освіти, екології і захисту моря [2]. Ведення противником гібридних дій щодо перешкоджання іiі провадження нашою державою обумовлює необхідність захисту вказаної діяльності. До видів морської діяльності, що потребують захисту, належать: торговельне мореплавство (зокрема, захист портів); морський транспорт; використання водних біоресурсів та інших ресурсів моря; діяльність щодо вивчення, розвідки, видобування, використання, збереження невідновних i відтворення відновних ресурсів, які не належать до водних біоресурсів.

Так, на сьогодні сили ЧФ ПдВО РФ активно ведуть гібридні дії щодо перешкоджання морегосподарській діяльності нашої держави та забезпечення незаконної економічної діяльності РФ у В(М)ЕЗ України. До основних видів такої діяльності відноситься видобуток мінеральних ресурсів і промисловий вилов риби. До того ж, Росія не лише продовжує видобуток енергетичних ресурсів 3 родовищ Чорного та Азовського морів, які розроблялись Україною до анексії Кримського півострова, а й розглядає можливість видобутку інших видів ресурсів прісної води 3 дна шельфу для забезпечення питною водою населення окупованого Криму, залізо-марганцевих конкрецій для потреб медицини та ін. [17].

Найбільші збитки Україна несе від втрати доступу до нафтогазових родовищ на шельфі. До анексії Криму наша держава видобувала нафту і газ з десяти родовищ, а нині під контролем України лише одне 3 них родовище "Стрілкове" в західній частині Азовського моря.

Загальний об'єм незаконного видобутого РФ газу за період з 2014 по 2019 роки складає 9,4 млрд м $^{3}$ (у середньому 1,57 млрд $\mathrm{M}^{3}$ ), об'єм прогнозованого видобутку до 2025 року - 9,5 млрд м ${ }^{3}$ [18].

Як результат, збитки України з 2014 по 2019 рік лише через незаконний видобуток РФ газу складають близько 1,88 млрд дол., а прогнозовані збитки до 2025 року - 1,9 млрд дол. (при середній ціні газу 200 дол. за $1000 \mathrm{~m}^{3}$ ). До того ж, ціна нового корабля класу “корвет" складає близько 300 млн дол. Отже, співвідношення втрат, які наша держава несе внаслідок незаконного видобутку РФ газу, є неспіврозмірними необхідним витратам на розвиток сил ВМС 3С України для перешкоджання протиправній економічній діяльності противника на морі.

Дії противника щодо перешкоджання нашій економічній діяльності на морі характеризуються гібридним впливом на цю діяльність.

До гібридних дій сил ЧФ ПдВО РФ щодо перешкоджання економічній діяльності України на морі відносяться:

обмеження судноплавства в Азовському морі шляхом будівництва мосту через Керченську протоку;

затримка та тривала перевірка торговельних суден на підходах до Керченської протоки, які рухаються до/з портів України в Азовському морі;

необгрунтоване і неправомірне закриття для судноплавства районів моря, через які проходять рекомендовані шляхи суден до/3 портів України в Чорному морі;

періодичні затримання рибальських суден у Чорному та Азовському морях, арешт ї екіпажів.

Не виключається можливість залучення сил ЧФ ПдВО РФ, які виконують завдання 3 охорони газових родовищ у районах, наближених до території України, до затримання та доглядів суден за азовським сценарієм [11].

До того ж, аналіз складу та стану корабельного складу ЧФ ПдВО РФ, який може залучатись до виконання завдань щодо перешкоджання веденню нашою державою економічної діяльності на морі [19], свідчить про його суттєву кількісну перевагу над корабельним складом ВMC 3С України (табл. 1). Як наслідок, ця перевага не дає 
змогу ефективно виконувати завдання нашими силами щодо захисту зазначеної діяльності в усій акваторії Чорного та Азовського морів.

Як відомо, ефективність застосування сил (військ) значною мірою залежить від умов навколишнього середовища. Зазначене потребує проведення аналізу району виконання завдань силами (військами) ВМС 3С України під час виконання завдань захисту економічної діяльності держави на морі.

Просторові розміри Чорного моря характеризуються значними відстанями (найбільша протяжність із заходу на схід 1150 км, 3 півночі на південь - 580 км), що обумовлює необхідність виконання силами завдань захисту економічної діяльності держави у віддаленні від пунктів базування. Просторові розміри Азовського моря значно менші (найбільша протяжність із заходу на схід - 380 км, 3 півночі на південь - 200 км), що дає змогу надводним кораблям здійснювати розгортання в райони виконання завдань у короткі терміни.

Клімат у цілому сприяє діям військ, однак вплив атлантичних циклонів узимку може ускладнювати плавання кораблів i застосування ними зброї, а низькі температури можуть призвести до потужного льодоутворення, що зі свого боку ускладнює або зовсім виключає плавання кораблів i застосування ними зброї.

Таблиця 1

Співвідношення кількості бойових кораблів та катерів ВМС ЗС України та ЧФ ПдВО РФ, які можуть залучатися до виконання завдань захисту / перешкоджання веденню економічної діяльності України на морі

\begin{tabular}{|l|c|c|c|}
\hline \multicolumn{1}{|c|}{ Сили та засоби сторін } & ВМС ЗС України & Співвідношення & ЧФ ПдВО РФ \\
\hline крейсери & - & & 1 \\
\hline сторожові кораблі / фрегати & 1 & $1: 5$ & 5 \\
\hline малі ракетні кораблі & - & & 6 \\
\hline протичовнові кораблі & - & & 7 \\
\hline десантні кораблі & 1 & & 2 \\
\hline патрульні кораблі & - & $1: 7$ & 7 \\
\hline мінно-тральні кораблі & 1 & $1: 4$ & 4 \\
\hline розвідувальні кораблі & 1 & & 5 \\
\hline підводні човни & - & $1: 5$ & - \\
\hline ракетні катери & 1 & $1: 4,5$ & 9 \\
\hline артилерійські катери & 11 & & - \\
\hline патрульні катери & 2 & & - \\
\hline десантні катери & 1 & $\mathbf{1}$ & $\mathbf{6 0}$ \\
\hline $\begin{array}{l}\text { протидиверсійні катери } \\
\text { сагальне співвідношення сил }\end{array}$ & $\mathbf{2 0}$ & \\
\hline
\end{tabular}

Хвилювання понад 4 бали, яке можна очікувати взимку 3 імовірністю до $30 \%$, ускладнює застосування бойових катерів [20].

Система базування ВМС ЗС України на Чорному морі не розвинена та налічує лише два пункти базування (Одеса, Очаків), що не дає змоги здійснювати розосереджене базування сил.

Відсутність пунктів базування ВМС 3С України в Азовському морі негативно впливає на організацію всебічного забезпечення та відновлення боєздатності катерів і суден (базування корабельного складу здійснюється на орендованих причалах у портах Бердянськ i Маріуполь).

Система берегового спостереження ВМС ЗС України забезпечує висвітлення морської обстановки лише в ближній морській зоні.
Загалом, характеристика районів i їx оперативне обладнання частково сприяє виконанню завдань.

Одним 3 основних внутрішніх чинників, який впливає на ефективність застосування ВМС ЗС України, є наявний склад, стан, оперативні (бойові) спроможності сил (військ), які можуть залучатися до виконання завдань.

Як зазначалося, на сьогодні до складу ВМС 3С України входить 20 бойових кораблів і катерів [21]. Більшість бойових катерів (за винятком патрульних), має низькі морехідні якості та обмежену автономність [22], яка не дає змогу залучати їх протягом тривалого часу до виконання завдань поза межами територіального моря та в осінньо-зимовий період.

Пріоритети розвитку спроможностей ВМС ЗС України до 2035 року визначено в [23]. Аналіз цього документа свідчить про 
можливість набуття спроможностей щодо контролю В(M)E3 (Sea Control) не раніше 2030 року, оскільки їх розвиток сплановано здійснити протягом другого етапу (2025 2030 рр.) розвитку спроможностей ВМС 3С України.

I хоча на сьогодні відпрацювання документів середньостроковго планування у сферах національної безпеки і оборони за напрямом розвитку 3С України (Державна програма розвитку ЗС України до 2025 року, Програми розвитку видів (родів) 3С України тощо) не завершено, напрями розвитку корабельного складу ВМС 3С України та ї спроможностей можливо визначити за інформацією 3 офіційних джерел та інформаційних ресурсів, які спеціалізуються на висвітленні питань розвитку озброєння.

Так, відповідно до інформації 3 відкритих інформаційних ресурсів, у найближчий період бойовий склад флоту планується поповнити завдяки: отриманню як міжнародної технічної допомоги патрульних катерів типу “Island"; придбанню патрульних катерів Mark VI; отриманню катерів вітчизняного будівництва за контрактами, які були укладені в попередніх роках та створенню і будівництву ракетних катерів за спільним українсько-британським проєктом. До того ж, переважна більшість 3 них (патрульні катери Mark VI, десантно-штурмові та броньовані артилерійські катери) за своїми тактико-технічними характеристиками $[22,24]$ не спроможні до довготривалого виконання завдань поза межами територіального моря та в осінньо-зимовий період. Отже прийняття їх до складу ВМС ЗС України хоча і підвищить бойовий потенціал флоту в цілому, але суттєво не вплине на підвищення спроможностей щодо захисту економічної діяльності на морі.

Водночас, слід відмітити низький рівень укомплектованості органів військового управління ВMC ЗС України, управлінь дивізіонів та екіпажів кораблів, що негативно впливає на якість підготовки та виконання силами завдань у морі.

Крім того, на ефективність застосування (військ) впливає також наявність і якість керівних документів, які визначають їх завдання та способи виконання цих завдань.

Так, відповідно до Тимчасової доктрини застосування ВМС ЗС України, виконувати завдання із захисту економічної діяльності держави на морі передбачається як у воєнний час, так і в умовах гібридних дій противника [25]. Однак обгрунтованого та докладного переліку завдань захисту економічної діяльності та способів виконання таких завдань керівними документами ВМС ЗС України не визначено. Як наслідок, указані завдання виконуються несистемно та епізодично.

\section{Висновки}

1. В умовах збройної агресії РФ Україна продовжує нести значні економічні збитки. Зазначене обумовлює необхідність вирішення питання обгрунтування переліку завдань щодо захисту економічної діяльності держави на морі та способів їх виконання силами (військами) ВМС ЗС України.

2. Невирішеність питання щодо делімітації державного кордону між Україною та РФ в Азовському морі та Керченській протоці, а також умови Договору про співробітництво, дають змогу противнику сприймати всю їх акваторію як свої внутрішні води та територіальне море, а також блокувати вільний прохід в Азовське море військових кораблів як третіх країн, так i України. Це дає змогу діяти силам ЧФ ПдВО РФ у всій акваторії Азовського моря, обмежує можливості щодо нарощування корабельного складу ВМС 3С України в Азовському морі та не дає змоги залучати кораблі ВМС країн партнерів до спільних дій, що негативно впливає на виконання завдань силами (військами) ВМС ЗС України в цій акваторії.

3. Після анексії Криму та втрати контролю над прилеглими до півострова водами і більшою частиною В(М)Е3, характер економічної діяльності України на морі зазнав суттєвих змін, які потребують врахування під час визначення переліку завдань щодо захисту економічної діяльності держави на морі.

4. Основними загрозами веденню Україною економічної діяльності на морі на середньострокову перспективу залишаються дії сил ЧФ ПдВО РФ щодо перешкоджання морегосподарській діяльності нашій державі в контрольованих противником акваторіях.

5. Кількісна та якісна перевага ЧФ ПдВО РФ над ВМС ЗС України обмежує просторові розміри району виконання завдань захисту економічної діяльності держави на морі силами (військами) ВМС ЗС України.

6. Переважна частина корабельного складу ВМС ЗС України не спроможна виконувати завдання щодо захисту економічної діяльності держави на морі протягом тривалого часу поза межами територіального моря та в осінньо-зимовий період. Зазначене потребує врахування під час 
визначення способів виконання завдань силами (військами) ВМС ЗС України.

7. В існуючих керівних документах 3 питань застосування ВМС не визначено перелік завдань щодо захисту економічної діяльності держави на морі та способи їх виконання, що негативно впливає на ефективність виконання цих завдань силами (військами) ВМС 3С України.

Напрями подальших досліджень. Проведений аналіз чинників, що впливають на ефективність застосування ВMC для виконання завдань захисту економічної діяльності держави на морі в умовах гібридних дій противника, надалі дає змогу обгрунтувати перелік завдань щодо захисту економічної діяльності держави на морі та способи їх виконання силами (військами) ВМС ЗС України.

\section{СПИСОК ВИКОРИСТАНОЇ ЛІТЕРАТУРИ}

1. Яким'як С. В. Розвиток України як морської держави: пріоритети державної морської політики в умовах збройної агресії РФ. Морська стратегія держави. Розвиток та реалізаиія морського потенціалу Украӥни : матеріали міжнар. наук. форуму, м. Київ, 24-25 трав. 2016 р. Київ, 2016. С. 12-25.

2. Морська доктрина України на період до 2035 року : затв. Постановою Кабінету Міністрів України від 07.10.2009 р. № 1307 (у редакції Постанови Кабінету Міністрів України від 18.12 2018 № $\quad 1108)$. URL: https://zakon.rada.gov.ua/laws/show/1307-2009-

$\% \mathrm{D} 0 \% \mathrm{BF} \#$ Text (дата звернення: 01.12.2020).

3. Про рішення Ради національної безпеки і оборони України від 14 вересня 2020 року “Про Стратегію національної безпеки України” : Указ Президента України від 14.09 .2020 р. № 392/2020. URL: https://www.president.gov.ua/documents/392202035037 (дата звернення: 01.12.2020).

4. Російська політика в Чорноморському регіоні: загрози й виклики для України : аналіт. доп. / О. Александров, А. Филипенко, Р. Власенко та ін.] ; за заг. ред. І. Веремія, М. Паламарчука. Київ : НІСД, 2020. $37 \mathrm{c}$.

5. Кабаненко I. В., Риженко А. О. ВійськовоМорські Сили України: час діяти. Чорноморська безпека : аналітичний часопис. Київ, 2020. № 2 (38). C. 33-38.

6. Бабін Б. В. Силові органи України та окупація Криму. Чорноморська безпека : аналітичний часопис. Київ, 2020. № 2 (38). С. 76-82.

7. Тарасов А. А. Основні погляди на концепцію розвитку Військово-Морських Сил Збройних Сил України. Реформа та модель Військово-Морських Сил Збройних Сил України. Морська стратегія держави. Розвиток та реалізачія морського потенціалу України : матеріали міжнар. опер.- стратег. семінару в межах міжнар. наук. форуму, м. Київ, 28 квіт. 2015 р. Київ, 2015. С. 7-19.

8. Клименко А. В. Російське озеро. Дев'ять аспектів сучасного Чорноморського контексту. Морська стратегія держави. Розвиток та реалізаиія морського потенціалу України : матеріали міжнар. наук. форуму, м. Київ, 22-23 трав. 2019 р. Київ, 2019. C. 12-19.

9. Риженко А. О. Сфера діяльності ВійськовоМорських Сил Збройних Сил України щодо забезпечення морської безпеки України. Морська стратегія держави. Розвиток та реалізаиія морського потенціалу України : матеріали міжнар. наук. форуму, м. Київ, 22-23 трав. 2019 р. Київ, 2019. C. $19-24$.

10. Соколюк С. М. Захист морської діяльності у виключній (морській) економічній зоні україни та інших районах відкритого моря. Морська стратегія держави. Розвиток та реалізаиія морського потенціалу України : матеріали міжнар. наук. форуму, м. Київ, 24-25 трав. 2016 р. Київ, 2016. C. 59-63.

11. Клименко А. В. Сценарії дій на морі на 2020 рік. Протидія гібридній війні на морі: уроки та висновки : матеріали круглого столу, м. Київ, 25 лют. 2020 р. Київ, 2020. С. 32-42.

12. Яким'як С. В. Проблемні питання протидії гібридному впливу противника на морі та шляхи ïх вирішення. Наука і оборона. 2020. № 2. С. 3136.

13. Воєнні аспекти протидії "гібридній агресії”: досвід України : монографія / колектив авторів ; за заг.ред. А. М. Сиротенка. Київ : НУОУ імені Івана Черняховського, 2020. $176 \mathrm{c.}$

14. Санніков С. Г., $\quad$ Раджапакса Й. К. Аналіз чинників, які впливають на ефективність застосування Військово-Морських Сил у інтересах забезпечення безпеки економічної діяльності держави. Труди університету : зб. наук. праць. Київ, 2013. № 5 (119). С. 53-60.

15. United Nations Convention on the Law of the Sea. URL: https://www.un.org/depts/los/ convention_agreements/texts/unclos/unclos_e.pdf (дата звернення: 01.12.2020).

16. Договір між Україною та Російською Федерацією про співробітництво у використанні Азовського моря і Керченської протоки. URL: https://zakon.rada.gov.ua/laws/show/643_205\#Text (дата звернення: 01.12.2020).

17. Пасынков А. А. Минеральные и топливноэнергетические ресурсы Черного моря (перспективы развития). Моря России: наука, безопасность, ресурсы : тезисы докл. научн. конф., г. Севастополь, 3-7 октября 2017 г. Севастополь, 2017. С. 100-102.

18. Черноморнефтегаз в 2019 г. остановил падение добычи газа. URL: https://neftegaz.ru/ news/dobycha/501855-udalos-chernomorneftegaz-v2019-g-ostanovil-padenie-dobychi-gaza (дата звернення: 01.12.2020). 
19. Черноморский флот. URL: https://www.kchf.ru/ship/today/today_all.htm (дата звернення: 01.12.2020).

20. Військово-географічні умови застосування сил (військ) Військово-Морських Сил : навч. посіб. / колектив авторів ; під заг. ред. С. В. Яким'яка. Київ : НУОУ імені Івана Черняховського, 2019. $172 \mathrm{c.}$

21. Військово-Морські Сили Збройних Сил України. URL: https://www.ukrmilitary.com/p/ukrainiannavy.html (дата звернення: 01.12.2020).

22. Озброєння та військова техніка ВійськовоМорських Сил Збройних Сил України : навч. вид. / колектив авторів ; за заг. ред. С. В. Яким'яка.
Київ : НУОУ імені Івана Черняховського, 2020. $96 \mathrm{c.}$

23. Стратегія Військово-Морських Сил Збройних Сил України 2035. Відновити - Захистити Перемогти. Одеса - Київ, 2018.

24. US Navy fields new Mark VI patrol boats. Navaltoday.com. URL: https:/www.navaltoday.com/ 2019/05/23/us-navy-fields-new-mark-vi-patrolboats/ (дата звернення: 01.12.2020).

25. Тимчасова доктрина застосування ВійськовоМорських Сил Збройних Сил України : затв. наказом Командування ВMC 3С України від 08.04.2019 р. № 80. Одеса, 2019. 207 с.

Стаття надійшла до редакційної колегії 17.12.2020

\section{Analysis of factors that may effect on the effectiveness of use the Navy duties during the protection of the economic activities of the state at sea in the context of hybrid enemy actions}

\section{Annotation}

After the capture of Crimea, the Russian Federation exercises control over a large part of the territorial sea, (maritime) economic zone of Ukraine. Many production facilities at sea, maritime infrastructure and other components of Ukraine's maritime potential have been affected. In addition to the above, the Russian Federation not only conducts illegal economic activities but also carries out hybrid operations to prevent Ukraine from implementing maritime economic activities. All this necessitates the involvement of units of the Navy of the Armed Forces of Ukraine in the protection of the national interests of our state.

The issues of conducting hybrid actions by the Russian Federation at sea, their impact on the conduct of economic activities in Ukraine, the use of the Navy of the Armed Forces of Ukraine to perform tasks to counter the enemy are well covered in recent scientific papers. This paper highlights the analysis of the impact of factors on the effectiveness of the use of forces (troops) in carrying out the tasks of protecting the economic activities of the state at sea during hybrid actions of the enemy. The analysis of this area has not been previously conducted comprehensively and has not been the subject of a separate study in previous works.

In research paper external and internal factors that affect the use of the Navy of the Armed Forces of Ukraine in carrying out tasks to protect the economic activities of the state at sea is identified. The general analysis of features and character of their influence on efficiency of use of forces (troops) is carried out also.

A number of restrictions have been identified, due to these factors, on the spatial and temporal indicators of the performance of tasks by the forces of the Navy of the Armed Forces of Ukraine, as well as the methods of their performance.

It is established that currently a clear list of tasks to protect the economic activity of the state at sea and ways to implement them in the current guidelines on the application of the Navy of the Armed Forces of Ukraine are not defined, so their implementation is unsystematic and sporadic.

The necessity of substantiation of the list of tasks and expedient ways of their performance by the forces (troops) of the Navy of the Armed Forces of Ukraine for effective protection of economic activity of Ukraine in the sea is pointed out. actions.

Keywords: naval forces; protection of maritime economic activities; external and internal factors; hybrid 